\title{
Chorea-acanthocytosis: a case report
}

This article was published in the following Dove Press journal:

International Medical Case Reports Journal

23 February 2016

Number of times this article has been viewed

\section{Lekhjung Thapa' \\ Suman Bhattarai' \\ Milan P Shrestha' \\ Rajesh Panth ${ }^{2}$ \\ Dinesh Nath Gongal ${ }^{3}$ \\ Upendra Prasad Devkota ${ }^{3}$ \\ 'Department of Neurology, \\ ${ }^{2}$ Department of Pathology, \\ ${ }^{3}$ Department of Neurosurgery, \\ National Institute of Neurological and \\ Allied Sciences, Kathmandu, Nepal}

Video abstract

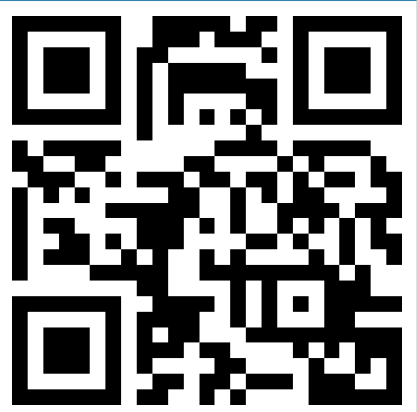

Point your SmartPhone at the code above. If you have a $Q R$ code reader the video abstract will appear. Or use: http://youtu.be/aCzGidywgPA

Correspondence: Lekhjung Thapa Department of Neurology, National Institute of Neurological and Allied Sciences, Bansbari, Kathmandu 44606, Nepal

Tel +977 | 9842 04 | 214

Fax +977 I 4370779

Email drlekhjung@gmail.com
Abstract: Neuroacanthocytosis is a group of rare disorders. We report a 36-year-old righthanded female who presented with gradually progressive abnormal facial movements, generalized weakness, and lower-lip biting starting 4 years ago. On examination, she had lower-lip ulcer, orofacial dyskinesias, and peripheral neuropathy. Her peripheral blood smears showed acanthocytosis and magnetic resonance imaging revealed atrophied head of caudate nuclei and putaminal hyperintensities on T2-weighted and fluid attenuated inversion recovery images. Work-up for autoimmune and metabolic causes was negative. She was diagnosed with choreaacanthocytosis, an entity under neuroacanthocytosis syndrome and the patient was offered symptomatic treatment.

Keywords: acanthocytes, lip-biting, neuroacanthocytosis, orofacial dyskinesia, movement disorder

\section{Introduction}

Neuroacanthocytosis (NA) is a group of very rare disorders estimated to have affected $\sim 1,000$ people worldwide. NA are complex, progressive, and incurable disorders and their treatment is symptomatic. The complex presentations that include a hyperkinetic movement disorder, a polyneuropathy, cognitive decline, and elevated creatine kinase (CK) raise the suspicion of a NA syndrome. To our knowledge, this is the first case report of NA from Nepal.

\section{Case report}

A 36-year-old right-handed female had presented with gradually worsening abnormal facial movements associated with intermittent rapid brief forceful eyes closure, perioral movements, and lower-lip biting. Her husband reported a history of difficulty in speaking, swallowing, and weakness of all four limbs, and she was wheelchairbound. She was born to a nonconsanguineous parent and lacked a family history of neurological disease. She was not exposed to long-term medications known to cause extrapyramidal dysfunction.

Examination revealed orofaciolingual dyskinesias mimicking suckling and grimacing, and lower-lip ulcer because of repeated biting (Figure 1). Mini Mental Status Examination (MMSE) could not be performed because of unintelligible speech. She had wasting of all four limbs, diminished power (4/5) and reflexes. Her fundus and sensory examinations were normal. Kayser-Fleicher (KF) ring, cerebellar signs, and autonomic dysfunction were absent. 

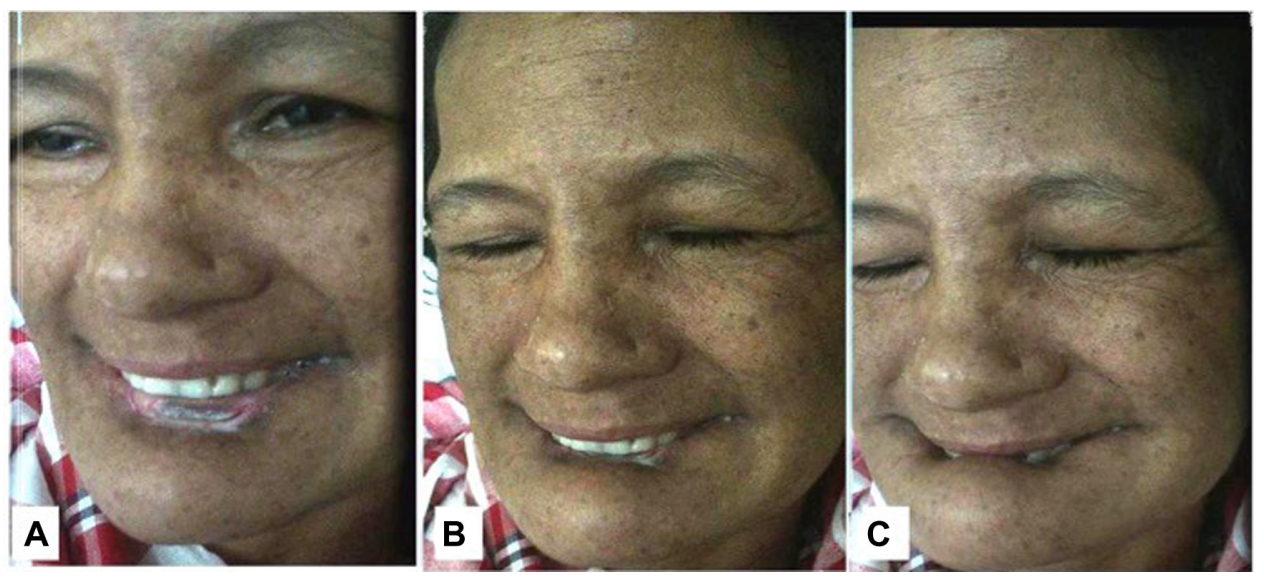

Figure I (A-C) Sequential snapshots from video demonstrating involuntary movements with closure of both eyes and lower-lip biting. Note: Lower-lip ulcer can be clearly seen in (A).

Peripheral smear examination performed following standard protocol ${ }^{1}$ showed acanthocytes (Figure 2) and magnetic resonance imaging showed degenerative changes in basal ganglia (Figure 3). Her CK was raised (528 U/L [Normal: up to 165 $\mathrm{U} / \mathrm{L}]$ ). Nerve conduction study showed peripheral mixed axonal neuropathy. Complete blood count, liver function test, random blood sugar, renal function test, antinuclear antibody, double stranded DNA, serum copper, serum ceruloplasmin, HIV, hepatitis B antigen, hepatitis C, cerebrospinal fluid analysis, USG abdomen, ECG, and echocardiography were normal.

She was treated with haloperidol and clonazepam. On follow-up at 3 months, her condition was static.

\section{Ethics}

Written informed consent was obtained from the patient to publish case details and pictures. Ethical clearance was also



Figure 2 Peripheral blood smear showing acanthocytes (red arrows). obtained from the National Institute of Neurological and Allied Sciences Ethical Review Board.

\section{Discussion}

NA syndrome disorders are all exceedingly rare, but also very likely to be underdiagnosed. ${ }^{2}$ It is estimated that $500-1,000$ people worldwide have chorea-acanthocytosis (ChAc), an entity under NA syndrome. ${ }^{3}$ ChAc is more prevalent in Japan. ${ }^{4}$ As literature search did not reveal any documentation of ChAc from Nepal, we believe that this is the first reported case of ChAc from Nepal.

ChAc is a progressive neurodegenerative autosomal recessive disorder. Its neurological symptoms usually manifest in the twenties. ${ }^{5}$ NA was first described in 1960 as "Levine-Critchley syndrome" 6 and as mentioned earlier, ChAc is one of the entities under NA. Other entities include: McLeod syndrome (MLS), Huntington's disease like 2 (HDL2), and pantothenate kinase-associated neurodegeneration.

Our diagnosis of $\mathrm{ChAc}$ was based on clinical ground and laboratory findings. Clinically, our patient had adultonset illness, hence, our diagnosis was restricted to either ChAc or MLS because HDL2 and pantothenate kinaseassociated neurodegeneration have a childhood or juvenile onset, and HDL2 is usually found in patients with African ancestry. MLS is an X-linked disorder that has predominant cardiovascular manifestations (our patient's cardiovascular status was normal). Also, lip biting is exceedingly rare in MLS. This feature with female sex in our case rules out MLS.

ChAc consists of choreoathetoid movement disorder with orofacial dyskinesia and progressive cognitive decline. The movement problems worsen with age. In few cases, 


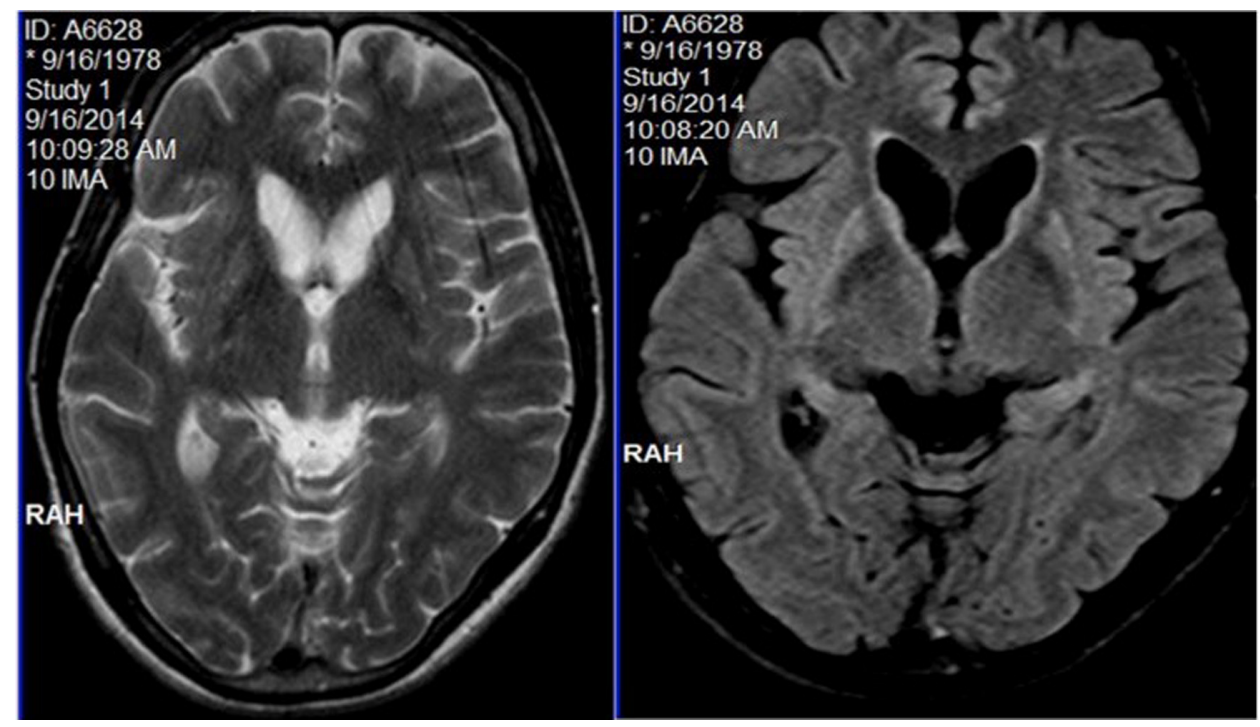

Figure 3 MRI showing caudate atrophy and striatal hyperintensities in both T2WI and FLAIR sequences.

Abbreviations: MRI, magnetic resonance imaging; T2WI, T2 weighted image; FLAIR, fluid attenuated inversion recovery; RAH, right anterior head position.

seizures may precede movement disorders by a decade. ${ }^{7}$ The characteristic phenotype includes chorea, a very peculiar "feeding dystonia" with tongue protrusion, ${ }^{8}$ orofacial dyskinesias, involuntary vocalizations, dysarthria, and involuntary tongue- and lip-biting. All these mentioned features were prominent manifestations of our case. The gait of ChAc patients may have a "rubber man" appearance with truncal instability and sudden, violent trunk spasms. ${ }^{9}$ We could not examine gait because of weakness. Behavioral changes are a common feature and may be the first presenting feature.

Clinical neuromuscular manifestations include areflexia, sensorimotor neuropathy, and variable weakness and atrophy. ${ }^{4}$ Most ChAc patients have elevated levels of CK. ${ }^{4}$ Our patient had all of these findings known to be typical manifestation of ChAc.

ChAc is caused by various mutations of a 73 exon gene on chromosome 9, VPS13A, coding for chorein. ${ }^{6} 10$ Confirmatory DNA analysis of the large VPS13A gene is difficult, due to the large gene size and heterogeneity of mutation sites. ${ }^{11-13}$ However, absence of chorein in erythrocytes can be demonstrated on Western blot. ${ }^{14}$ Chorein is implicated in intracellular protein sorting but its physiological functions are not yet known. ${ }^{4}$ We did not test for chorein because of financial constraints although protein testing is available free of charge. ${ }^{15}$

We diagnosed the case as ChAc based on history and also because acanthocytes were readily documented in peripheral smear with elevated serum CK level. The elevated CK level suggested presence of myopathy, an important diagnostic clue to NA syndrome, however, her relative declined electromyography test. Acanthocytosis may be absent in peripheral blood smears and a negative screen does not reliably exclude an NA syndrome. ${ }^{16}$

Neurodegeneration affects predominantly the caudate nucleus, putamen, and globus pallidus. In ChAc, thalamus and substantia nigra are also involved. ${ }^{4}$ In magnetic resonance imaging, we observed changes in all these mentioned regions. Computed tomography scan did not show calcification in the aforementioned regions.

So far no curative or disease-modifying treatments are available. Recognition of treatable complications such as seizures, and swallowing problems are essential. Neuropsychiatric issues are more amenable to pharmacotherapy. Dopamine antagonists or depleters such as clozapine or tetrabenazine may ameliorate the movement disorders. Results of deep brain stimulation (DBS) in ChAc are mixed. ${ }^{17-19}$ NA disorders have a relentlessly progressive course and are eventually fatal. Sudden death may be attributable to seizure or autonomic dysfunction. Early identification of the case may avoid the need for invasive and nondiagnostic tests such as muscle, bone marrow, or liver biopsy and help guide the proper management and counseling.

\section{Conclusion}

This rare disorder should be considered in the differential diagnosis of atypical cases of epilepsy, peripheral neuropathy, and behavioral disorder associated with movement disorder. 


\section{Acknowledgment}

The authors would like to thank Prof Madhu Dixit Devkota, Dr Samarth Singh, and all the Magister Chirurgiae Registrars of National Institute of Neurological and Allied Sciences.

\section{Disclosure}

The authors report no conflicts of interest in this work.

\section{References}

1. Storch A, Kornhass M, Schwarz J. Testing for acanthocytosis A prospective reader-blinded study in movement disorder patients. J Neurol. 2005;252:84-90.

2. Jung HH, Danek A, Walker RH. Neuroacanthocytosis syndromes. Orphanet J Rare Dis. 2011;6:68.

3. Chorea-acanthocytosis. Genetic home reference. Available from: http:// ghr.nlm.nih.gov/condition/chorea-acanthocytosis. Accessed May 30, 2015.

4. Ueno S, Maruki Y, Nakamura M, et al. The gene encoding a newly discovered protein, chorein, is mutated in chorea-acanthocytosis. Nat Genet. 2001;28(2):121-122.

5. Walker RH, Jung HH, Dobson-Stone C, et al. Neurologic phenotypes associated with acanthocytosis. Neurology. 2007;68:92-98.

6. Danek A, editor. Neuroacanthocytosis Syndromes. Dordrecht, Springer Verlag; 2005:5-7.

7. Al-Asmi A, Jansen AC, Badhwar A, et al. Familial temporal lobe epilepsy as a presenting feature of choreoacanthocytosis. Epilepsia. 2005;46(8):1256-1263.

8. Bader B, Walker RH, Vogel M, et al. Tongue protrusion and feeding dystonia: a hallmark of chorea-acanthocytosis. Mov Disord. 2010;25(1):127-129.
9. Schneider SA, Lang AE, Moro E, Bader B, Danek A, Bhatia KP. Characteristic head drops and axial extension in advanced choreaacanthocytosis. Mov Disord. 2010;25(10):1487-1491.

10. Rampoldi L, Dobson-Stone C, Rubio JP, et al. A conserved sortingassociated protein is mutant in chorea-acanthocytosis. Nat Genet. 2001;28(2):119-120.

11. Allen FH, Krabbe SMR, Corcoran PA. A new phenotype (McLeod) in the Kell blood-group system. Vox Sang. 1961;6:555-560.

12. Marsh WL, Taswell HF, Øyen R, Nichols ME, Vergera MS, Pineda AA. $\mathrm{Kx}$ antigen of the Kell system and its relationship to chronic granulomatous disease. Evidence the $\mathrm{Kx}$ gene is X-linked. Transfusion. $1975 ; 15: 527$

13. Marsh WL, Marsh NJ, Moore A, et al. Elevated serum creatine phosphokinase in subjects with McLeod syndrome. Vox Sang. 1981;40(6):403-411.

14. Dobson-Stone C, Velayos-Baeza A, Filippone LA, et al. Chorein detection for the diagnosis of chorea-acanthocytosis. Ann Neurol. 2004;56(2):299-302.

15. EHDN-Neuroacanthocytosis submodule. Available from: https://www. euro-hd.net/edit/na/network/docs/na-blood-sampling-instructions.pdf. Accessed August 23, 2015

16. Sorrentino G, De Renzo A, Miniello S, Nori O, Bonavita V. Late appearance of acanthocytes during the course of chorea-acanthocytosis. J Neurol Sci. 1999;163(2):175-178.

17. Wihl G, Volkmann J, Allert N, Lehrke RE, Sturm V, Freund HJ. Deep brain stimulation of the internal pallidum did not improve chorea in a patient with neuro-acanthocytosis. Mov Disord. 2001;16(3):572-575.

18. Burbaud P, Rougier A, Ferrer X, et al. Improvement of severe trunk spasms by bilateral high-frequency stimulation of the motor thalamus in a patient with chorea-acanthocytosis. Mov Disord. 2002;17(1):204-207.

19. Burbaud P, Vital A, Rougier A, et al. Minimal tissue damage after stimulation of the motor thalamus in a case of chorea-acanthocytosis. Neurology. 2002;59(12):1982-1984.
International Medical Case Reports Journal

\section{Publish your work in this journal}

The International Medical Case Reports Journal is an international, peer-reviewed open-access journal publishing original case reports from all medical specialties. Previously unpublished medical posters are also accepted relating to any area of clinical or preclinical science. Submissions should not normally exceed 2,000 words or

\section{Dovepress}

4 published pages including figures, diagrams and references. The manuscript management system is completely online and includes a very quick and fair peer-review system, which is all easy to use. Visit http://www.dovepress.com/testimonials.php to read real quotes from published authors. 